\title{
The effect of agricultural product eco-labelling on green purchase intention
}

\author{
Ha Thu Nguyen ${ }^{a^{*}}$ and Hieu Trung Le ${ }^{a}$
}

\begin{tabular}{l}
${ }^{a}$ University of Economics and Busine \\
\hline C H R O N I C L E \\
\hline Article history: \\
Received: January 19, 2020 \\
Received in revised format: \\
March 252020 \\
Accepted: April 20, 2020 \\
Available online: \\
April 20, 2020 \\
\hline Keywords: \\
Green Consumption \\
Green Purchase Intention \\
Eco-label \\
Vietnam
\end{tabular}

\section{A B S T R A C T}

Green consumption trends are changing the intention of consumers' choices and purchases. Ecological labels form the role of stimulating acts of purchasing environmentally friendly products and transmitting green product messages. Based on synthetic of intentional behavioral models and theory, this paper presents the results of an empirical study investigating the relationship between ecolabel knowledge, consumer's trust, perceived value, environmental concern, and consumer attitudes from one side and green purchase intention of agricultural products of Hanoi consumers from the other side. Correlation and path analysis are applied to analyze the data collected from the questionnaire survey in Hanoi, Vietnam from December 2018 to March 2019. The analytical results reveal the significant impact of perceived value and environmental concern on consumer attitude which leads to higher green purchase intention. This study helps to clarify new marketing forms through eco-labels, propose management solutions to governments and businesses in such developing countries as Vietnam.

\section{Introduction}

From the sustainability perspective, over the past few decades, human consumption has increased rapidly and uncontrolled which create the consequences of damaging and overuse of natural resources (Chen \& Chai, 2010). Green consumption was formed as a practical and effective solution to solve environmental urgent problems. As regarded as a new trend in the 2000s, green consumption is gradually spread over the world. Above all, modern consumers have a better sense of consumption, give priority to use and are willing to spend at a premium price on green products (Gordon-Wilson \& Modi, 2015). Besides, many governments are now involved in environmental protection toward achieving sustainable development goals. Falcone (2018) affirmed that more capital investment in green development strategy helps create sustainable development value for the economy and by means of that, creating long-term value for businesses. In front of social needs and changes in green consumption demand, businesses quickly seize opportunities, integrate green marketing in production and business activities. Green marketing is often regarded as marketing practices, activities aimed at conveying messages to consumers in various marketing aspects (e.g., planning, processing, promotion, people) with the goal of minimizing the environmental impact of products and services (Groening et al., 2018). The three main tools of green marketing include (i) ecological brand; (ii) eco-labels; (iii) environmental advertisement (Rahbar et al., 2011). The WTO definition of eco-labels is a type of certification for products that meet certain environmental criteria provided by a government agency or an authorized organization. The appearance of labels contributes two main roles: information function and corporate social responsibility function (Søerserskov \& Daugbjerg, 2011). From the perspective of information, ecological labels certify the reliability of products, reduce ambiguity and hesitation in selecting process, green messages to help consumers easily assess products, improve their intention to purchase green products (Rahbar et al., 2011). In such developed countries like Germany, Canada, and The United States; the eco-label programs have been developed intensively, becoming a sustainable development criterion of the country. Ecological label 
programs such as 1978's "Blue Angel" in Germany, 1988's "The Ecologo" in Canada are typical examples of eco-label programs that benefit the public as a source of financing to government, enterprise product certification and reinforce consumer belief. Besides, in developing countries, typically China, the eco-label program was started in 1993 responding to the sustainable idea proposed in United Nation Conference on Environment and Development - with the name China Environmental Labelling. Not only that, following the success of its, China has developed two new label programs to serve the nation's sustainable development goals: China energy Conservation Program 1998 and China Water Conservation Certification 2004. In such developing country like Vietnam, the Vietnam Environment Administration inherits the eco-label program abroad, adding the information to the definition that eco-label certifies products with a higher level of environmental priority than other type products on the basis of evaluating the entire cycle of the life cycle. The Vietnam eco-label program called "Vietnam Green Label" was constructed by the Vietnam Ministry of Natural Resources and Environment in 2009. In the following years, eco-label issues have been attracted more attention from Vietnamese businesses. Many producers in plastic, food and agricultural sectors paid attention on registering for eco-label certification at relative high cost while consumers are experienced some difficulties in selecting eco-label product when there are so many different forms of labels on the market and also the existing of uncertified eco-labels. While eco-label issues became more important in such developing countries as Vietnam, the literature review indicates a limited number of domestic-related materials and the available articles did not provide an analytical framework analyze the effects of ecological labels on green behavior and intentions in the context of developing countries.

To fill the gap on green consumption literature, this study aims at developing a framework to analyze the factors affecting consumer attitudes and the green purchase intention on agricultural products. Based on analytical results, this study suggests some solutions for Vietnamese governments and businesses to maximize the economic and social benefits of green products and encourage the consumption towards eco-label products. The next section of this paper summarizes the literature on green consumption, which is followed by the presentations of analytical framework, hypotheses development, data collections and analysis. The last sections present the implications, limitations, and conclusions.

\section{Literature review}

\subsection{Green products}

The European Union Commission (2001) defines green products as products that use fewer resources, lower risks to the environment and less waste generation. According to Dangelico and Pontrandolfo (2010), green products are products that have a good impact and minimize the negative effects of related products. Understandably, green products do not necessarily have to be "green" itself but in many ways such as package, transportation and auxiliary elements that make products more prone to be environmental friendliness. McDaghagh and Prothero (1997) point out that there are countless approaches to comprehend the word "green", such as biological friendliness, politics, social responsibility, fair trade, conservation, nonprofit, new consumption, sustainability, equality. Currently, companies develop production strategies with the goal of "greening" products and services according to market needs and opportunities due to law, competition and ecological responsibility (Bansal \& Roth, 2000; González-Benito \& González-Benito, 2006; Murillo-Luna et al., 2008); leading to the strategy of environmentally friendly sustainable development becomes one of the competitive strengths in the market (Unruh \& Ettenson, 2010). Green products in agriculture generally look in many ways, one of which can be regarded as organic products, cultivate processes, packaging, no pesticides (De Haes et al., 2010). Hence, green agricultural products can be easily certified through a variety of features that are geared to consumers' tastes and concerns for the environment.

\subsection{Eco-label}

As mentioned in the introduction, eco-label is one of three useful tools in stimulating consumers to use green products. It involves two main functional roles: (i) information functions and (ii) functions of corporate social responsibility. In this paper, the study focuses on ecolabel information functionality to clarify the impact on consumer attitudes and green buying intentions. According to De Haes (2010), the information function affecting businesses in two directions of market decision are (i) target products customers, (ii) business customers in the supply chain. Common keywords on eco-label products in the transmission of environmental objectives are "eco-friendly", "environmental safety", "recyclable", "biodegradable", "ozonefriendly" (D'Souza et al., 2006). Eco-labels help the company shape green consumer customer files, using differentiation strategies in competition and increasing product value. Certification of product through eco-labels eliminates information gaps between buyers and sellers, demonstrates the product's environmental message, convinces users about the honesty of the item. Green products are charged with a higher selling price than traditional products of the same type, so buyers will assess and determine the value of the offer, which can be shortened by direct certification of ecological labels (Atkinson \& Rosenthal, 2014). Consumers ready to pay more for eco-label products because of the need for standardized product and progressive cognitive values (Prieto et al., 2016). In summary, we see three main reasons for promoting the use of eco-labels for products: (1) the ecological effectiveness of products, (2) the depth and breadth of messages conveyed by governments and associations, (3) strategic value and innovation of the business. However, eco-labels exist certain limitations that affect businesses and product consumption processes, for instance: (i) the binding of rigid policies leads to complex business situations, (ii) ensuring product quality due to the high selling price of labeled products, (iii) impact on other products without labels, (iv) trade barriers in accordance with WTO on public procurement policy (De Haes et al., 2010). 
The eco-label is attached to agricultural products according to a basic certification system, classified by cultivating process or by product type. In general, there are three methods of eco-labeling for agricultural products: industrial ecolabel, sustainable natural resource certificate, and Fair-trade label. Eco-labels inform the characteristics of agricultural products (e.g.: nutrition, flavor, chemicals used) or agricultural farming methods (pesticides, working conditions, time of cultivation). The reason for the information function of the product is related to the quality more than the environmental factors due to the specific characteristics of agricultural products, consumers understand green agriculture is good for the environment. In addition, according to research by Pirog (2003) in Iowa, the United States shows that consumers would rather purchase green agricultural products due to the "freshness" and nutrition than the superiority of environmental factors. With the perspective in the quality, green agricultural products bring a better flavor and healthier body. In particular, consumers try to equip with the knowledge about the agricultural product season, the distance of transporting products to the sale place to meet the needs of choosing the right fresh product. Thus, the eco-label for food can be seen as a form of transmitting product quality messages to consumers (Nilsson et al., 2014).

\subsection{Green purchase intention}

The study of Ajzen (1991) in the theory of planned behavioral (TPB), the intention is a direct and objective factor to explain people behavior. The model shows the intention is the intermediate factor captures the motivation from "attitude", "subjective norm", "perceived behavioral control", then promotes real performance behavior. Hence, the higher the intention lead to the easier behavior happen, however, in addition to internal human factors, external factors also play the important roles but do not mention in the model like opportunities and resources (e.g.: time, money, skills). The green purchase intention is the development coming from the common purchase intention, adding customers' inside motivation of the environment protection. Chan (2001) defines "green purchasing refers to the purchase of environmentally friendly products and avoiding products that harm the environment". Another view is that the green purchase intention is the desire and ability of a person to pay for the environmentally friendly characteristics of the product compared to traditional products (Rashid, 2009). The perspectives of scholars have separate points but generally, clarifying the subjective intention of the individual to pay for the environmentally friendly characteristics of the product. The study of Groening et al., (2018) summarizes empirical frameworks are used in previous studies to analyze green purchase intention and green behavior. In general, the theories are divided into 6 groups, namely: values and knowledge, trust, attitudes, intentions, motivation, social confirmation. Theories are popular including: Attitude Theory, Attitude-behavior Theory, Theory of Planned Behavior (TPB), Consumer Choice Theory, Rational Choice Theory, and Adaptation Theory, and the most widely used the TPB model. Besides, there are many factors that impact on green purchase intention including individual and situational elements which have been studied by authors from 2000 until now. The individual factors such as emotions, habits, perceived consumer effectiveness, perceived behavioral control, values and personal norms, trust, knowledge, and lifestyle. The situational factors such as price, product availability, subjective norm/social norm and reference groups, product attributes, and quality, store related attributes, brand image, eco-labeling and certification, environment message (Joshi \& Rahman, 2015).

\section{Analytical framework}

In Vietnam context, eco-label studies are very limited, no analytical framework had been used to analyze the eco-label impact on consumer attitudes and green purchase intention. To answer our research questions, this study adopts TPB approach and focus on such aspects as attitude and intention because those aspects are shown very important in Vietnam. The reasons are: (i) the recognition of eco-label in the market is low, (ii) the impact of society on eco-label is not clear, (iii) the aim of this paper is to clarify the internal human factor for creating a base for future research. In addition, this study also adds other important factors found in recent literature studies to clarify consumer attitude when choosing green agricultural products. Based on TPB approach and recent literature, this study proposes an analytical framework on investigating the relationship between of eco-label knowledge, consumer's trust, perceived value, environmental concern, and consumer attitudes and green purchase intention of agricultural products as depicted in Fig. 1.

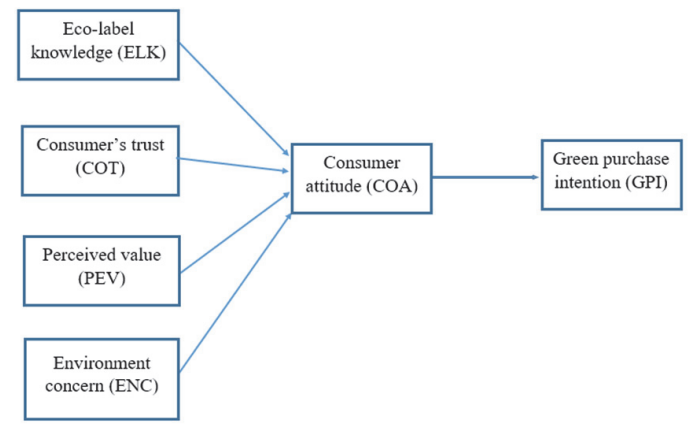

Fig 1. Analytical framework 
The first issue relates to the linkage between eco-label knowledge, consumer's trust, perceived value, environmental concern and consumer attitude. Daugbjerg et al. (2014) found the relationship of knowledge and consumer's trust impact on the behavior of purchasing organic eco-labels agricultural products. Besides, Schultz et al. (2014) and Taufique (2017) affirmed that eco-label, environmental knowledge contributes to reducing information gaps to stimulate product purchasing behavior, in addition, consumer's trust, perceived value, environmental concern also plays significant roles in raising the attitude toward the green product. Therefore, the first hypothesis can be presented as follows:

Hypothesis 1: Consumer attitude is directly related to eco-label knowledge, consumer's trust, perceived value, and environment concern.

The second issue relates to the linkage between eco-label knowledge, consumer's trust, perceived value, environmental concern, consumer attitude, and green purchase intention. From the TPB approach, attitude is often regarded as the most important factor affecting the intention and behavior of consumer products selection. Thøgersen et al. (2010), Atkinson and Rosenthal (2014) show the empirical evidence that positive attitudes should have a positive and significant impact on consumers' intention to purchase the green product. The attitude should act as an intermediary variable to explain the factors of belief, cognitive value or interest in the environment that forms the intention to buy green. Therefore, the second hypothesis can be presented as follows:

Hypothesis 2: Green purchase intention is directly related to consumer attitude and indirectly related to eco-label knowledge, consumer's trust, perceived value, and environment concern

To test the established hypotheses, based on recent empirical literature, the authors would like to utilize six constructs as follows.

- Eco-label knowledge assesses consumers' understanding of environmental protection, organic product concepts, and recognition of the eco-labels and its types. This measurement scale is constructed from 6 observed variables as shown in the Appendix.

- Consumer's trust assesses the level of trust of eco-label products and the validity of eco-labels in consumer perception. This measurement scale is constructed from 6 observed variables.

- Perceived value assesses subjective customer reviews of the surplus value of eco-labeled products compared to conventional products. This measurement scale is constructed from 5 observed variables.

- Environmental concern assesses the point of view of consumers' environmental protection at a level and readiness to take act. This measurement scale is constructed from 4 observed variables.

- Consumer attitude assesses customers' views on green consumption to identify opportunities for eco-label products. This measurement scale is constructed from 3 observed variables.

- Green purchase intention assesses the shifting trend in consumer purchasing green products with eco-label. This measurement scale is constructed from 4 observed variables.

The measurement scales have been adapted from the existing literature and then localized to match with Vietnam market context. English question items adopted from literature was translated into Vietnamese and tested by researchers, experts and consumers to make sure that the questionnaire was correctly translated and understandable.

\section{Data collection}

The questionnaire survey was conducted from December 2018 to March 2019 in Hanoi, Vietnam. The survey respondents are Vietnamese customers who already experienced in purchasing green agricultural products such as vegetables, fruits. Each survey respondent was asked to indicate his/her perception about how satisfied they were with question items on five-pointLikert scale $(1=$ Strongly Disagree, $2=$ Disagree, $3=$ Neutral, $4=$ Agree, $5=$ Strongly Agree). During 3 months, 160 printed questionnaire has been distributed and the authors finally get back 148 responses which account for $92.50 \%$. The characteristics of survey respondents are presented in Table 1.

Table 1

Demography of survey respondents

\begin{tabular}{|c|c|c|c|c|c|}
\hline \multirow[t]{2}{*}{ Gender } & Male & 45 & \multirow[t]{4}{*}{ Income per month } & Under 3 million VND & 85 \\
\hline & Female & 103 & & 3 - 8 million VND & 43 \\
\hline \multirow[t]{3}{*}{ Age } & $18-24$ & 110 & & 8 - 15 million VND & 17 \\
\hline & $25-39$ & 10 & & Over 15 million VND & 3 \\
\hline & Over 40 & 28 & \multirow[t]{4}{*}{ Eco-label recognition } & Attention & 87 \\
\hline \multirow[t]{3}{*}{ Occupation } & Student & 107 & & Notice & 42 \\
\hline & Worker & 11 & & Unmindful & 19 \\
\hline & Officer & 30 & & & \\
\hline
\end{tabular}




\section{Data analysis}

\subsection{Measurement Test}

The analytical process was started by testing the reliability and validity of collected data. As suggested in literature, the reliability was examined using Cronbach's Alpha with acceptance criteria is 0.6 and the results are presented in Table 2 which indicates high reliability and consistency for all six measurement scales.

Table 2

Measurement Test and Descriptive statistics

\begin{tabular}{|c|c|c|c|c|c|}
\hline $\begin{array}{r}\text { Scales } \\
\end{array}$ & Conbach's Alpha & Min & Max & Mean & Std. Dev. \\
\hline Eco-label knowledge & 0.87 & 1.00 & 5.00 & 3.37 & 0.75 \\
\hline Consumer's trust & 0.92 & 1.00 & 5.00 & 3.35 & 0.80 \\
\hline Perceived value & 0.86 & 1.00 & 5.00 & 3.71 & 0.72 \\
\hline Environmental concern & 0.88 & 1.00 & 5.00 & 3.95 & 0.79 \\
\hline Consumer attitude & 0.93 & 1.00 & 5.00 & 4.21 & 0.82 \\
\hline Green purchase intention & 0.93 & 1.00 & 5.00 & 4.05 & 0.78 \\
\hline
\end{tabular}

To test the validity, Confirmatory Factor Analysis was conducted and the results are shown in Fig. 2. As analysis in model fit test, the main coefficients: Chi-square p value, TLI, RMSEA, CFI - prove that the data is suitable to run path analysis. The only coefficient is not fit the recommend value is GFI (under 0.9), this paper considers that it's a sub factor and the mistake here was about the sample just enough. Based on reliability and validity test, the authors can conclude that the collected data is reliable and valid and can be used for further analysis.

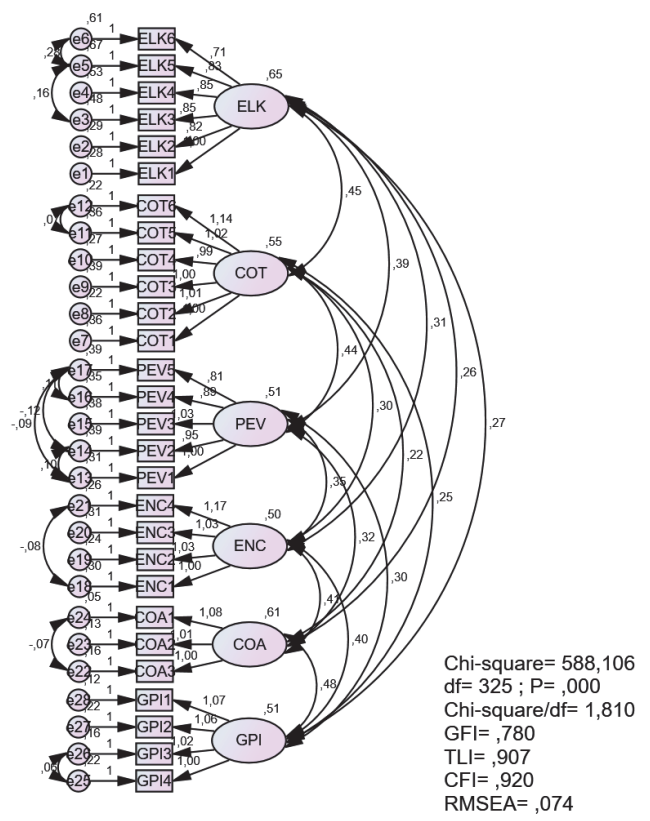

Fig 2. Confirmatory Factor Analysis

\subsection{Hypothesis Testing}

Path analysis is conducted to test the established framework on the relationship between eco-label knowledge, consumer's trust, perceived value, environmental concern, consumer attitude, and green purchase intention. Regression analyses are conducted to determine the standardized regression coefficients which were used to identify the path coefficient between each independent variable and dependent variable (significant levels set at $5 \%$ as suggested in the literature). The results of the regression are presented in Table 3 and the final path diagram is presented in Fig. 3.

Model 1: It was found that perceived value, environmental concern significantly impacts consumer attitude. A combination of label knowledge, consumer's trust, perceived value, and environmental concern can explain 52.10\% of the variability of consumer attitude.

Model 2: It was found that consumer attitude significantly impacts green purchase intention and can explains $64.90 \%$ of the variability of green purchase intention. 
Table 3

Summary of path analysis

\begin{tabular}{|c|c|c|c|c|c|c|c|}
\hline Dependent variable & $\mathbf{F}$ & $\mathbf{P}$ & $\mathbf{R 2}$ & Independent variables & B & Standardized B & $\mathbf{P}$ \\
\hline \multirow{4}{*}{ Consumer attitude } & \multirow{4}{*}{38.86} & \multirow{4}{*}{0.000} & \multirow{4}{*}{0.52} & Eco-label knowledge & -0.01 & -0.13 & 0.870 \\
\hline & & & & Consumer's trust & -0.15 & -0.15 & 0.120 \\
\hline & & & & Perceived value & 0.29 & 0.26 & 0.005 \\
\hline & & & & Environmental value & 0.65 & 0.63 & 0.000 \\
\hline Green purchase intention & 269.88 & 0.000 & 0.65 & Consumer attitude & 0.77 & 0.81 & 0.000 \\
\hline
\end{tabular}

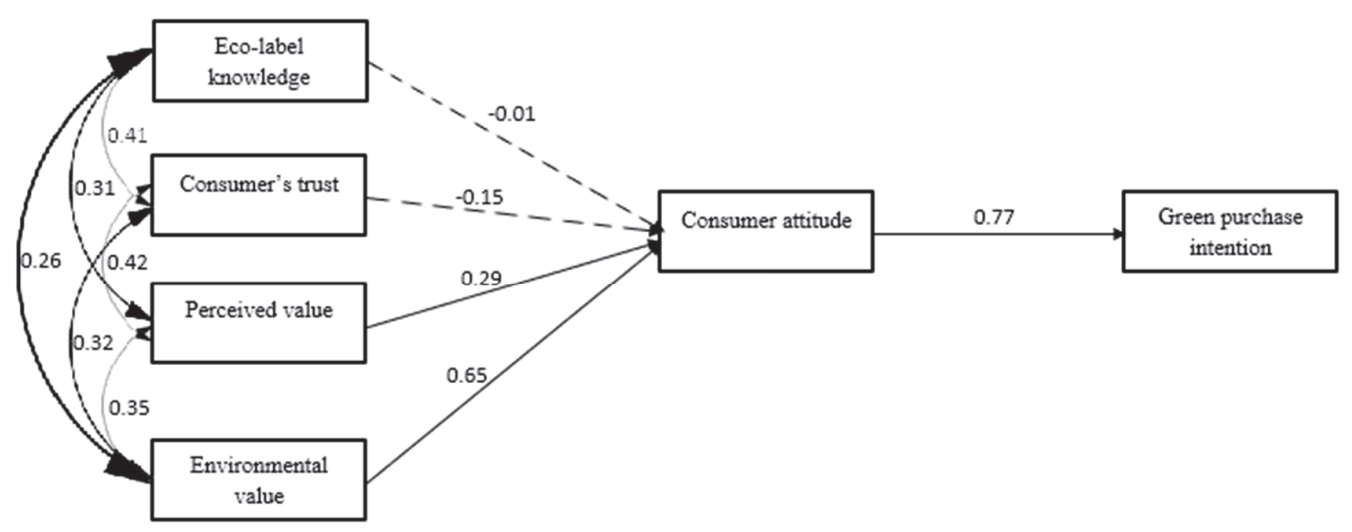

Fig. 3. Model summary

Next, standardized regression coefficients were used to calculate the path coefficients between variables, as summarized in Table 4. Fig. 3 describes the direct effects among variables based the results of path analysis. The arrows show direct connections between two variables along with values of direct effects. Path coefficients between perceived value and consumer attitude and green purchase intention, between environment concern and consumer attitude and green purchase intention are relative high while coefficients between eco-label knowledge/ consumer's trust and consumer attitude and green purchase intention is found to be lower than others. Table 5 summarizes model fit indexes which pass minimum acceptance levels recommended in the literature. The results of statistical analysis suggested that Hypotheses 1, and 2 should be accepted.

The correlations between all pairs of six variables were then decomposed into the sum of their direct and indirect effects.

Table 4

Decompositions of path coefficient

\begin{tabular}{|c|c|c|c|c|}
\hline Dependent variable & Independent variables & Direct effect & Indirect effect & Total effect \\
\hline \multirow{4}{*}{ Consumer attitude } & Eco-label knowledge & -0.01 & 0.00 & -0.01 \\
\hline & Consumer's trust & -0.15 & 0.00 & -0.15 \\
\hline & Perceived value & 0.26 & 0.00 & 0.26 \\
\hline & Environmental concern & 0.63 & 0.00 & 0.63 \\
\hline \multirow{5}{*}{ Green purchase intention } & Eco-label knowledge & 0.00 & -0.01 & -0.01 \\
\hline & Consumer's trust & 0.00 & -0.12 & -0.12 \\
\hline & Perceived value & 0.00 & 0.21 & 0.21 \\
\hline & Environmental concern & 0.00 & 0.51 & 0.51 \\
\hline & Consumer attitude & 0.81 & 0.00 & 0.81 \\
\hline
\end{tabular}

Table 5

Summary of model fitness

\begin{tabular}{lcc} 
& \multicolumn{1}{c}{ Model fit } & Recommend Value \\
\hline Chi square & & Value \\
Comparative Fit Index (CFI) & $\geq 0.90$ \\
Root Mean Square Error of Approximation (RMSEA, 90\% confidence interval) & $0.00 ; 0.08$ \\
Normed Fit Index (NFI) & $\geq 0.90$ \\
Incremental Fit Index (IFI) & $\geq 0.90$ \\
Goodness Fit Index (GFI) & $\geq 0.96$ \\
\hline
\end{tabular}

\section{Discussions, implication, and limitations}

The purpose of this research was to investigate the impact of eco-label on consumer intention in Hanoi - Vietnam. The authors focused on the process of formulating and implementing an analytical framework to explain the factors inside consumers to 
calculate their attitude forward eco-label agricultural product and green purchase intention. Previous sections presented the analytical framework, research hypotheses, and the results of path analysis with multiple regression models. The results of path analysis suggest that two hypotheses were partially supported. The main findings and implications for green agricultural product supplier are summarized below:

Firstly, the main findings of this study indicate the significant linkages between perceived value and consumer attitude and green purchase intention, between environmental concern and consumer attitude and green purchase intention. The results reveal the important roles of perceived value and environmental concern in the green agricultural product in Vietnam market. The environmental concern was found to strongly impact consumer attitude, which means the issue of protecting the environment contributes to motivating the consumer to purchase the green agricultural product. While the perceived value took up a smaller value in coefficient but it shows that the customer wants the green product to be good in return for the higher price charged, and be suitable to their aims of a healthy food lifestyle. Secondly, through analytical results and literature review, we offer product supplier to diversify product and label designs and functions to meet consumer needs. Customers perceive product value differently based on their perception, and they have their mind to evaluate which product is suitable for their desire. We offer that eco-label should contain a combination function to inform higher product value-added or create the ecolabel focus on society trend-line (for example carbon care, recycle, no plastic use ...). This approach makes the firm face some issue in changing aspects of production when integrating many functions into one. Thirdly, the supplier should select eco-label messages towards "fresh" products. As mention in Pirog (2003) research, the customer tends to choose fresh food for better taste and also realize "green", "environmentally friendly" as the good product that benefits for health care. Hence, eco-label should emphasize the utility of the product to health by adding messages of health, for instance: "a healthy heart", "organic", "healthy", "no pesticide", etc. Fourth, the supplier should implement marketing strategy focusing on the wide-area brand and enhancing the popularity of labels. Eco-label recognition is less popular, creating a barrier in building the trust of the product to the customer, thereby making the green message inefficient. We also recommend that the Vietnam Ministry of Natural Resources and Environment should take act to issue laws for encouraging the use of eco-label in the related field. On the other hand, Vietnamese firms need to advertise products in the way of adopting label in their product packages and sellingspace which is suitable with Vietnam customer's characteristics. (for the example grocery store, open market, supermarket). It is important to view this study in the context of its limitations. Methodologically, this study is based on data gathered via self-reported questionnaires, and individual bias in reporting may exist. Another issue is relatively small sample size time and resources constraints. Future research should be conducted with larger size which allows the researchers to use more comprehensive techniques. Future researchers could more focus on specific kinds of the eco - products such as food, lightning, paint, office equipment to understand the impact of society and consumer attitude toward intention and behavior.

\section{Conclusion}

The study focused on investigating the effects of eco-labels on the green purchase intention of Vietnam consumers for better understanding the changing needs and the trend on green consumption in such developing country like Vietnam. The findings of this study suggest that suppliers of green agricultural products should pay special attention to strengthening their image and enhance product benefits to raise customer's perceived value and take the environment messages in marketing strategy criteria. The paper provided an analytical framework to investigate the effects of eco-label knowledge, consumer's trust, perceived value, environmental concern, consumer attitude on green purchase intention, thereby, contributed to providing a base knowledge on potential segmentation about the eco-label product. The empirical evidence provided by this study would be useful for future research investigating the critical factors for promoting consumption in the green agricultural product for sustainable development in developing countries.

\section{References}

Atkinson, L., \& Rosenthal, S. (2014). Signaling the green sell: the influence of eco-label source, argument specificity, and product involvement on consumer trust. Journal of Advertising, 43(1), 33-45.

Ajzen, I. (1991). The theory of planned behavior. Organizational Behavior and Human Decision Processes, 50(2), $179-211$.

Bansal, P., \& Roth, K. (2000). Why companies go green: A model of ecological responsiveness. Academy of Management Journal, 43(4), 717-736.

Chen, T. B., \& Chai, L. T. (2010). Attitude towards the environment and green products: Consumers' perspective. Management Science and Engineering, 4(2), 27- 39.

Chan, R. Y. (2001). Determinants of Chinese consumers' green purchase behavior. Psychology \& Marketing, 18(4), $389-413$.

Daugbjerg, C., Smed, S., Andersen, L. M., \& Schvartzman, Y. (2014). Improving eco-labelling as an environmental policy instrument: Knowledge, trust and organic consumption. Journal of Environmental Policy \& Planning, 16(4), 559-575.

Dangelico, R. M., \& Pontrandolfo, P. (2010). From green product definitions and classifications to the Green Option Matrix. Journal of Cleaner Production, 18(16-17), 1608-1628.

De Haes, H. U., \& de Snoo, G. R. (2010). Eco-labelling of agricultural food products. In Environmental Assessment and Management in the Food Industry (pp. 374-397). Woodhead Publishing.

D'Souza, C., Taghian, M., \& Lamb, P. (2006). An empirical study on the influence of environmental labels on consumers. Corporate Communications: An International Journal, 11(2), 162-173.

Falcone, P. M. (2018). Green investment strategies and bank-firm relationship: A firm-level analysis. Economics. Bulletin, 38, 22252239. 
Groening, C., Sarkis, J., \& Zhu, Q. (2018). Green marketing consumer-level theory review: A compendium of applied theories and further research directions. Journal of Cleaner Production, 172, 1848-1866.

Gordon-Wilson, S., \& Modi, P. (2015). Personality and older consumers' green behaviour in the UK. Futures, 71, 1-10.

González-Benito, J., \& González-Benito, Ó. (2006). A review of determinant factors of environmental proactivity. Business Strategy and The Environment, 15(2), 87-102.

Joshi, Y., \& Rahman, Z. (2015). Factors affecting green purchase behaviour and future research directions. International Strategic Management Review, 3(1-2), 128-143.

Murillo-Luna, J. L., Garcés-Ayerbe, C., \& Rivera-Torres, P. (2008). Why do patterns of environmental response differ? A stakeholders' pressure approach. Strategic Management Journal, 29(11), 1225-1240.

McDonagh, P., \& Prothero, A. (1997). Green management: A reader. International Thomson Business Press.

Nilsson, A., Hansla, A., \& Biel, A. (2014). Feeling the green? Value orientation as a moderator of emotional response to green electricity. Journal of Applied Social Psychology, 44(10), 672-680.

Prieto-Sandoval, V., Alfaro, J. A., Mejía-Villa, A., \& Ormazabal, M. (2016). ECO-labels as a multidimensional research topic: Trends and opportunities. Journal of Cleaner Production, 135, 806-818.

Pirog, R. S. (2003). Ecolabel value assessment: Consumer and food business perceptions of local foods.

Rahbar, E., \& Abdul Wahid, N. (2011). Investigation of green marketing tools' effect on consumers' purchase behavior. Business Strategy Series, 12(2), 73-83.

Rashid, N. R. N. A. (2009). Awareness of eco-label in Malaysia's green marketing initiative. International Journal of Business and Management, 4(8), 132-141.

Sønderskov, K. M., \& Daugbjerg, C. (2011). The state and consumer confidence in eco-labeling: organic labeling in Denmark, Sweden, The United Kingdom and The United States. Agriculture and Human Values, 28(4), 507-517.

Schultz, P. W., Shriver, C., Tabanico, J. J., \& Khazian, A. M. (2004). Implicit connections with nature. Journal of Environmental Psychology, 24(1), 31-42.

Taufique, K. M. R., Vocino, A., \& Polonsky, M. J. (2017). The influence of ecolabel knowledge and trust on pro- environmental consumer behaviour in an emerging market. Journal of Strategic Marketing, 25(7), 511-529.

Thøgersen, J., Haugaard, P., \& Olesen, A. (2010). Consumer responses to ecolabels. European Journal of Marketing, 44(11/12), 1787-1810.

Unruh, G., \& Ettenson, R. (2010). Growing green. Harvard Business Review, 88(6).

\section{Appendix - Measurement instruments}

\begin{tabular}{|c|c|}
\hline Constructs and measurement items & References \\
\hline Eco-labelling knowledge & \multirow{7}{*}{$\begin{array}{l}\text { (Taufique et al., 2017) } \\
\text { (Thøgersen et al., 2010) }\end{array}$} \\
\hline I know the meaning of the term "recycled" in agricultural products. & \\
\hline I know the meaning of the term "eco-friendly" of agricultural products & \\
\hline I know the meaning of the term "organic" & \\
\hline I know the meaning of the term "energy-efficient" used in agricultural products & \\
\hline I can recognize the eco-label seal in agricultural products. & \\
\hline The eco-label on package provides information about environmental protection & \\
\hline Trust in eco-labelling & \multirow{7}{*}{$\begin{array}{l}\text { (Taufique et al., 2017) } \\
\text { (Chen and Chang, 2012) }\end{array}$} \\
\hline The label is genuinely committed to environmental protection & \\
\hline Most of what label say about its agricultural products is true & \\
\hline If the label makes a claim or promise about its product, it's probably true & \\
\hline I feel that this product's environmental performance is generally dependable & \\
\hline This product's environmental concern meets my expectations & \\
\hline This product keep promise and commitments for environmental protection & \\
\hline Perceived value in green product & \multirow{6}{*}{$\begin{array}{l}\text { (Spreng and Patterson, } \\
\text { 1997) } \\
\text { (Chen and Chang, 2012) }\end{array}$} \\
\hline This product's environmental functions provide very good value for me & \\
\hline This product's environmental performance meets your expectations & \\
\hline I purchase this product because it has more environmental concern than other products. & \\
\hline I Purchase this product because it is environmental friendly & \\
\hline I purchase this product because it has more environmental benefit than other products & \\
\hline Environmental concern & \multirow[t]{5}{*}{ (Lee, 2008) } \\
\hline I am worried about the worsening quality of the environment & \\
\hline The environment is my major concern & \\
\hline I am emotionally involved in environmental protection issues & \\
\hline I often think about how the environmental quality can be improved & \\
\hline Attitude toward green purchase & \multirow{4}{*}{$\begin{array}{l}\text { (Chan, 2001) } \\
\text { (Paul et al., 2016) }\end{array}$} \\
\hline I like the idea of purchasing green & \\
\hline Purchasing green is a good idea & \\
\hline I have a favorable attitude toward purchasing a green version of a product. & \\
\hline Green purchase intention & \multirow{5}{*}{$\begin{array}{l}\text { (Chan, 2001), } \\
\text { (Chen \& Chang, 2012) }\end{array}$} \\
\hline I will consider buying green product because they are less polluting & \\
\hline I plan to switch to other brands/versions green agricultural products & \\
\hline I intend to purchase this product in the future because of its environmental performance & \\
\hline I will buy green product in my next purchase. & \\
\hline
\end{tabular}

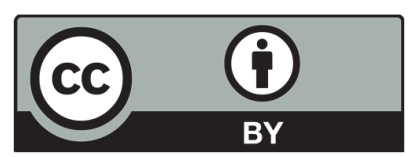

(C) 2020 by the authors; licensee Growing Science, Canada. This is an open access article distributed under the terms and conditions of the Creative Commons Attribution (CC-BY) license (http://creativecommons.org/licenses/by/4.0/). 